\title{
Embryo sac development in yellow passion fruit Passiflora edulis f. flavicarpa (Passifloraceae)
}

\author{
Margarete Magalhães de Souza ${ }^{1}$, Telma Nair Santana Pereira ${ }^{1}$, Magali Hoffmann ${ }^{2}$, Edésio J.T. de Melo ${ }^{3}$ \\ and Ricardo Pereira Louro ${ }^{4}$ \\ ${ }^{1}$ Laboratório de Melhoramento Genético Vegetal, Centro de Ciências e Tecnologias Agropecuárias, \\ Universidade Estadual do Norte Fluminense, Horto, RJ, Brazil. \\ ${ }^{2}$ Laboratório de Proteção de Plantas, Centro de Ciências e Tecnologias Agropecuárias, \\ Universidade Estadual do Norte Fluminense, Horto, RJ, Brazil. \\ ${ }^{3}$ Laboratório de Biologia Celular e Tecidual, Centro de Biociências e Biotecnologias, \\ Universidade Estadual do Norte Fluminense, Horto, RJ, Brazil. \\ ${ }^{4}$ Laboratório de Ultraestrutura Vegetal, Departamento de Botânica, Instituto de Biologia, \\ Centro de Ciências da Saúde, Universidade Federal do Rio de Janeiro, Rio de Janeiro, Brazil.
}

\begin{abstract}
The yellow passion fruit, Passiflora edulis f. flavicarpa, is one of the most important Brazilian fruit crops. It is an allogamous, diploid, and self-incompatible species. It has hermaphrodite, solitary flowers, located in the leaf axils and protected by leaf bracts. The flower has an androgynophore, which is a straight stalk supporting its reproductive parts. There are usually five anthers, located at the tip of each of the five filaments. The ovary is borne just above the filaments, at the top of the androgynophore; there are three styles that are united at their base, and at the top there are three stigmas. The objective of this research was to observe embryo sac development in yellow passion flowers. Ovaries at different stages of development were fixed in FAA (formalin, acetic acid and alcohol solution), hydrated, stained with Mayer's hemalum, and dehydrated. Ovules were cleared by using methyl salicylate, mounted on slides, and observed through a confocal scanning laser microscope. The yellow passion fruit ovule is bitegmic, crassinucellate, and anatropous, and its gametophyte development is of the Polygonum type. After meiosis, functional megaspores under go three successive mitotic divisions, resulting in an eight-nucleate megagametophyte: the egg apparatus at the micropylar end, two polar nuclei at the cell center, and three antipodals at the chalazal end. The egg apparatus is formed by an egg cell and two synergids, each with a filiform apparatus. The mature embryo sac has an egg cell, two synergids, two polar nuclei, and three antipodes, as has been described for most angiosperms.
\end{abstract}

Key words: egg cell, embryo sac, Passifloraceae, yellow passion fruit, Passiflora edulis f. flavicarpa Deg., confocal microscopy, megagametogenesis.

Received: April 4, 2002; accepted: October 4, 2002.

\section{Introduction}

Yellow passion fruit belongs to the order Passiflorales and the family Passifloraceae, which has 18 genera. There are two cultivated taxa: the purple, $P$. edulis f. edulis Sim., and the yellow, P. edulis f. flavicarpa Deg. The purple passion fruit is originally native from southern Brazil and Argentina; the yellow passion fruit occurs naturally in Brazil, being considered as a mutation of the purple variety, or as a natural hybrid between $P$. edulis f. edulis

Send correspondence to Telma N.S. Pereira, Laboratório de MeIhoramento Genético Vegetal, Centro de Ciências e Tecnologias Agropecuárias, Universidade Estadual do Norte Fluminense, Av. Alberto Lamego 2000, 28013-600, Horto, RJ, Brazil. E-mail: telmasp@uenf.br. and another related species (Vanderplank, 1991) The difference between them is due to anthocyanin pigmentation of stems and fruit.

Yellow passion fruit is an allogamous, diploid, selfincompatible species. It is an herbaceous or woody vine, climbing by tendrils, which are usually solitary in the axil of the leaf. It has hermaphrodite, solitary flowers, located in the leaf axils, and protected by leaf bracts. The flower has an androgynophore, which is a straight stalk supporting its reproductive parts. There are usually five anthers at the tip of the five filaments. The ovary is borne just above the filaments, at the top of the androgynophore. There are three styles that are united at their base, and at the top there are three stigmas (Figure 1 and 2) (Vanderplank, 1991). 


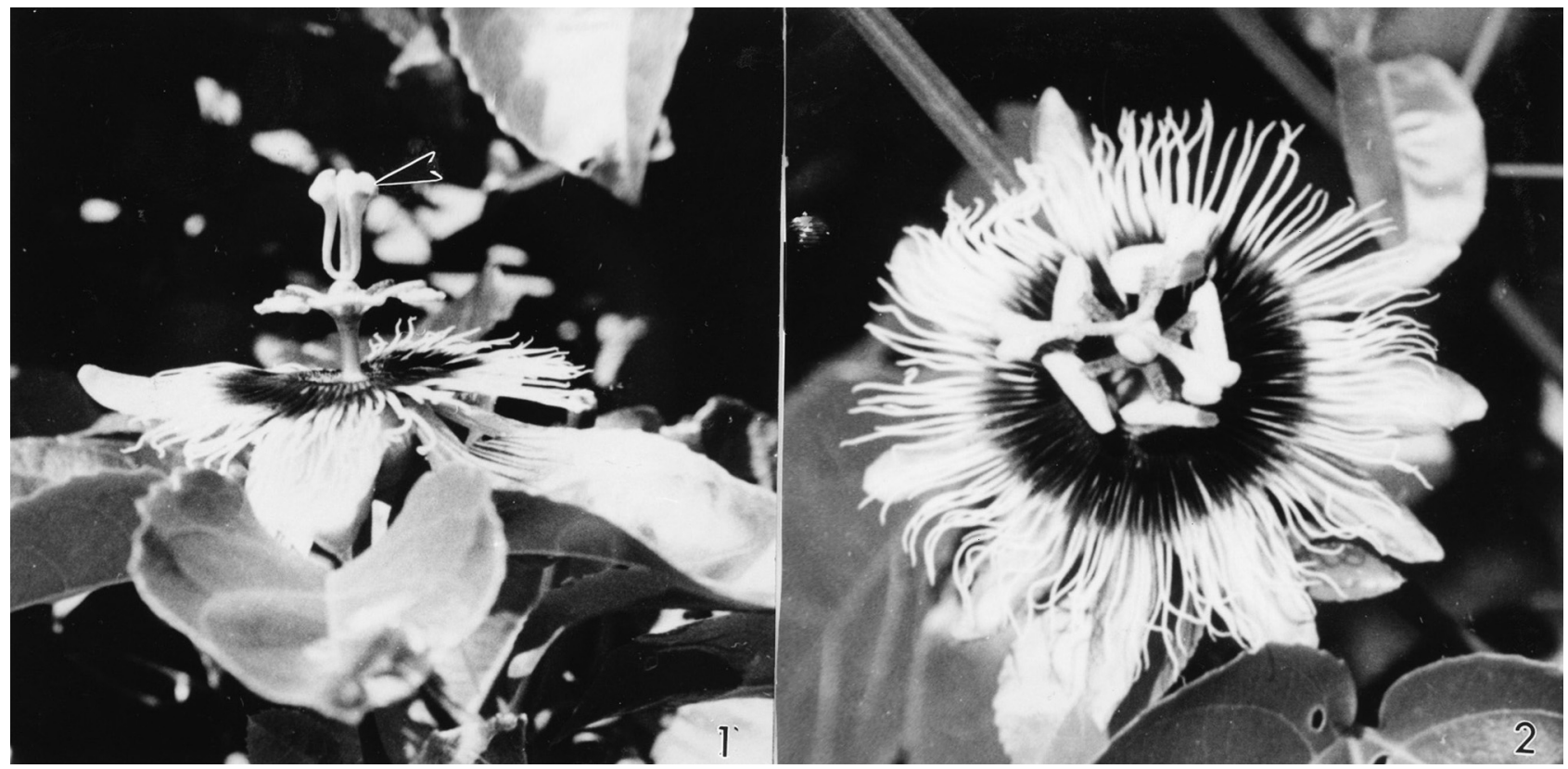

Figures 1-2 - Flowers of yellow passion fruit. 1. Flower at opening moment, showing the style in an upright position. 2. Flower, minutes after opening, showing the completely curved styles.

The yellow passion flower opens at noon; at that moment, its style is in an upright position, but it starts curving a few minutes after the flower opening. According to the style curvature, there are three kinds of flowers in the yellow passion plant: a) completely curved (CC) flowers, where the style curves in such a way as to bring the stigmas close to the anthers; b) partially curved (PC) flowers, where the style curves partially, but the stigmas remain above the anthers, forming a $45^{\circ}$ angle with them; and c) flowers without curvature (WC), where the style does not curve, and the stigmas form an angle of approximately $90^{\circ}$ with the anthers; the period of curvature is around $71 \mathrm{~min}$ (Ruggiero, 1973). The three flower types can be found on a single plant; however, CC flowers are the most common, and WC flowers are the less common ones (Ruggiero, 1973). The flowers do not have any marker distinguishing them before the style curves, and no genetic information is available for this trait. The frequency of WC flowers can vary from 0 to $50 \%$ of flowers on a single plant. When they are used as pollen source, fructification occurs; but, when they are used as female parent, fructification does not occur, even after hand pollination, suggesting an abnormality in the female gametophyte (Ruggiero, Lam-Sanchez and Miguel, 1976).

The embryo sac development involves two events: megasporogenesis and megagametogenesis. The first comprises the stages of development of the functional megaspore, and the latter corresponds to the female gametophyte (embryo sac) development itself. In megasporogenesis, a single hypodermal cell enlarges and differentiates from the other sporophytic cells in the nucellus, becoming the mega- spore mother cell (MMC). The MMC undergoes meiosis, resulting in a linear tetrad of haploid nuclei. Three nuclei degenerate, and the chalazal one undergoes three mitotic divisions, usually resulting in a cell with eight nuclei. The number of megaspore nuclei may vary, due to variations in meiosis, cytokinesis, period and number of mitotic divisions (Maheshwari, 1950; Reiser and Fischer, 1993; Cameron and Prakash, 1994). Megagametogenesis is highly coordinated with the sporophytic tissue of the ovule (Grossniklaus and Schneitz, 1998).

The female gametophyte (megagametophyte) is a product of the ovule, because inside it occur megasporocyte differentiation, production of a functional megaspore (megasporogenesis), formation of the embryo sac (megagametogenesis), and embryogenesis (Reiser and Fischer, 1993).

The process leading to the mature embryo sac may differ, but its organization, in most angiosperms, follows the same pattern. At the time of fertilization, the embryo sac presents the tricellular egg apparatus, with the egg cell and two synergids, three antipodal and two nuclei in the cell center, fused or not. These cells take part in the fertilization, embryogenesis, and nutrition of the embryo sac and embryo (Maheshwari, 1950; Kapil and Bhatnagar, 1981; Reiser and Fischer, 1993; Chamberlin et al., 1994). So far, no developmental studies on megagametogenesis in yellow or purple passion fruit are known to have been published. Since the ovule represents the main female reproductive organ, the objective of this research was to study the development of the embryo sac in the flower of the yellow passion fruit. 


\section{Material and Methods}

Flower buds at different stages of development were fixed in FAA. Ovules were dissected out of the ovaries, yet maintained connected to the ovary wall by the placenta. Fixation was done for $24 \mathrm{~h}$ at $4{ }^{\circ} \mathrm{C}$. After water rinse, the ovules were hydrated for $20 \mathrm{~min}$, stained with Mayer's hemalum solution (Diagnostica MERCK) for $20 \mathrm{~min}$, and destained in 2\% acetic acid for 20 min. Dehydration was performed in an ethanol series up to $100 \%$, which was gradually replaced by methylsalicylate (Pereira et al., 1997). The ovules from the same ovary were mounted in methylsalicylate on slides; cover slips were placed on the preparations and sealed with nail polish. Slides were examined immediately after preparation.

Mounted ovules were observed through a confocal scanning laser microscope (CSLM) (ZEISS LSM 410 invert) with an excitation wavelength of $488 \mathrm{~nm}$, and an emission wavelength of $543 \mathrm{~nm}$. The ovules were optically sectioned at a thickness of $1 \mu \mathrm{m}$.

\section{Results and Discussion}

The ovules of the yellow passion fruit are bitegmic, anatropous, and crassinucellate. Although some species, such as Potentilla nivea (Eriksen and Frederickson, 2000), may present more than one archesporial cell, in the yellow passion fruit, each ovule presents one embryo sac, originated from an archesporial cell. A cell from the nucellus grows in size and enters meiosis, resulting in one functional and three non-functional megaspores. The functional megaspore undergoes three successive mitotic divisions, resulting in a seven-cell, eight-nucleated mature embryo sac. Cell formation of the embryo sac occurs during the migration of the polar nuclei. The mature embryo sac is rich in starch grains. The embryo sac formation follows the Polygonum type, as described for about $70 \%$ of the angiosperm species (Maheshwari, 1950; Reiser and Fischer, 1993).

The ovule may have one or two, internal and external, integuments, and this number is constant for most families (Maheshwari, 1950). The internal integument originates, in most cases, from the derma, and the external integument derives from the derma and hypoderma levels. During megaspore development, the integuments grow parallel to the nucleus until covering it completely. In the yellow passion fruit, the first morphological change that occurs in the ovule primordium is the emergence of the integuments, whose growth is the result of anticlinal cell division along with directed cell elongation, as described by Gasser, Broadhvest and Hauser (1998). There are two integuments: the outer integument which covers the inner integument, until they meet each other and form the micropyle (Figure $3)$. In the young ovule, there is a space between the integuments and the nucellus; however, this space disappears as the nucellus grows. Also in Herminium monorchis (Orchidaceae), two integuments are formed, but only the internal integument forms the micropyle (Frederickson, 1990).

Much work has been done in order to elucidate the role of integuments in the development of the embryo sac. In Arabidopsis silvestre and female-sterile mutants, interdependence between the normal formation of the integuments and the embryo sac was found. It was observed that, in those mutants, the integuments presented abnormalities in their formation, and that, although the archesporial cells were able to differentiate, they resulted in the formation of an abnormal embryo sac (Robinson-Beers et al., 1992). Studies conducted by Baker et al. (1997) in Arabidopsis silvestre demonstrated that the Inner no outer $(I N O)$ and Aintegumenta (ANT) genes are essential for the development of the integuments in that species, confirming the interdependence between the presence of the internal tegument and the embryo sac.

The antipodal cells are located on the opposite side of the egg cell, they are usually three, frequently varying in size (Maheshwari, 1950; Cameron and Prakash, 1994) and in number, as it occurs with the number of nuclei of these cells, as recorded in the Compositae family. The antipodals can achieve a high level of polyploidy, indicating high metabolic activity, analogous to the behavior of the tapetum cells in the anther (Maheshwari, 1950). In the embryo sac of the yellow passion fruit, antipodals were observed in only a few ovules. They were positioned at the chalazal end of the gametophyte, and had a triangular shape (Figure 4); their nuclei were small, as compared to other nuclei in the gametophyte. The antipodals were ephemeral, as in many other species, such as Vicia faba (Johansson and Wales, 1993). Sometimes the antipodals were absent, as reported for species from the sub-family Papilionoideae (Cameron and Prakash, 1994), and sometimes they were found after fertilization (Frederickson, 1990). In this study, antipodals were found in young ovules, and it is possible that they contribute to the megagametophyte and/or embryo sac, by producing large quantities of starch in the central cells, as it occurs in mature ovules.

In the yellow passion fruit, the central cell showed two polar nuclei, one coming from the chalazal region (Figure 5), and the other from the micropylar region. They migrated to the center of the central cell, where they could fuse. Sometimes, the polar nuclei remained separated, or only partially fused, until fertilization (Figure 6). When they were fused, they shared the same cytoplasm, but had two small nucleoli. Fusion usually occurred immediately prior to fertilization, when the polar nuclei come close to the egg apparatus. Partial fusion of polar nuclei has been observed in other species (Reiser and Fischer, 1993; Cameron and Prakash, 1994). According to Kapil and Bhatnagar (1981), before pollination, the membranes of the polar nuclei may fuse at one point, but the complete fusion occurs only after the sperm nucleus reaches the partially fused polar nuclei. There are records, however, of complete 

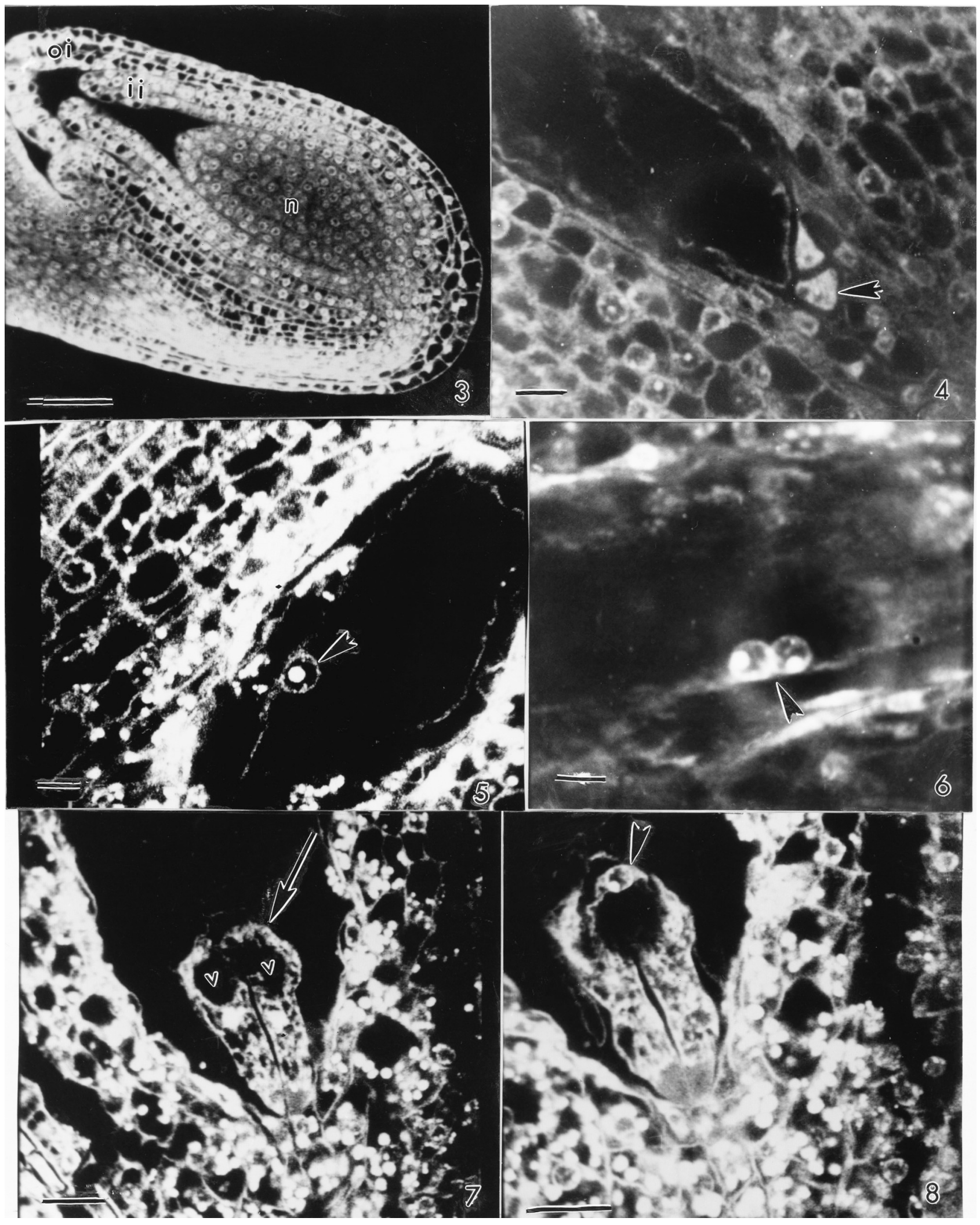

Figures 3-8 - Components of the yellow passion fruit embryo sac. 3. Anatropous ovule showing the outer (oi) and inner (ii) integuments, and the nucellus (n); bar $=50 \mu \mathrm{m}$. 4. Antipodals at the chalazal end (arrowhead); bar $=10 \mu \mathrm{m}$. 5. Polar nuclei (arrowhead); bar $=10 \mu \mathrm{m} ; 6$. Polar nuclei (arrowhead); bar $=$ $10 \mu \mathrm{m} ; 7$. Synergids (arrow) showing the nucleus at the micropylar end, and the fissure between them; bar $=25 \mu \mathrm{m} ; \mathbf{8}$. Egg apparatus showing the nucleus at the chalazal end (arrowhead); bar $=10 \mu \mathrm{m}$. 
fusion of the polar nuclei before fertilization in Capsella and Stipa. In soybean, the polar nuclei are partially fused, presenting two nucleoli right after the fusion, and a large nucleolus only at the beginning of the pollen tube penetration (Kennell and Horner, 1985). In the yellow passionfruit, since the flower buds were collected before opening, so pollination/ fertilization had not yet occurred, the two polar nuclei were not completely fused.

In this study, the egg apparatus, with two synergids and an egg cell, was at the micropylar end. Each synergid (Figure 7), adjacent to the egg cell, had a vacuole at the chalazal end, and cytoplasm with a nucleus in the micropylar region. There was a fissure between the synergids. The filiform apparatus was not well defined, probably because the ovule clearing technique does not allow to observe it (Kennell and Horner, 1985; Pereira et al., 1997). The synergids are usually ephemeral structures which disappear before or immediately after fertilization (Maheshwari, 1950). They play an important role in fertilization, because the pollen tube addresses its content inside one of the synergids before the incorporation of the spermatic nuclei by the egg and central cells (Reiser and Fischer, 1993). It is well known that there are high concentrations of $\mathrm{Ca}^{2+}$ inside the synergids, one of which usually degenerates before or at the time of the arrival of the pollen tube, which penetrates the degenerated synergid cell. The apex of the pollen tube releases itself and frees the spermatic cells (Cheung, 1996). In the yellow passion fruit, both synergids were observed in the mature embryo sac, possibly due to the fact that it is an allogamous species. The flower is only pollinated shortly after opening, in contrast to autogamous plants, where one of the synergids degenerates immediately after the opening of the flower, moments before pollination occurs.

The egg cell has a vacuole at its micropylar end, and cytoplasm with a nucleus at the chalazal end (Figure 8). No abnormalities were observed during embryo sac development in the yellow passion fruit; so the sterility observed in WC flowers cannot be explained by the absence of the egg cell, as reported by Pereira et al. (1997); maybe there is no egg cell after the embryo sac development. Lack of fruit set can be due to many factors, such as stigma, style, embryo abortion, abnormal endosperm, and not just to an abnormal gametophyte.

Our observations represent the most complete survey of embryo sac development in yellow passion fruit to date. The results are consistent with the pattern described for other taxa with Polygonum-type development. What makes this research significant are the following aspects: it concerns a very important Brazilian crop; it presents an analysis of the developmental process of megagametogenesis, and may serve as a basis for comparison among the three types of flowers reported in the yellow passion fruit.

\section{Acknowledgments}

The authors thank Dr. Reid G. Palmer for the critical reading and FENORTE for research support.

\section{References}

Baker SC, Robinson-Beers K, Villaneuva JM, Gaiser JC and Gasser CS (1997) Interactions among genes regulating ovule development in Arabidopsis thaliana. Genetics 145:1109-1124.

Cameron BG and Prakash N (1994) Variations of the megagametophyte in the Papilionoidea. Advances in legume systematics 6: Structural Botany, pp 97-115.

Chamberlin MA, Horner HT and Palmer RG (1994) Early endosperm, embryo, and ovule development in Glycine max (L.) Merr Plant Sci 155(4):421-436.

Cheung AY (1996) Pollen-pistil interactions during pollen-tube grow. Elsevier Science 1:45-51.

Eriksen B and Frederickson M (2000) Megagametophyte development in Potentilla nivea (Rosaceae) from Northern Swedish Lapland. American Journal of Botany, 87(5):642-651.

Frederickson M (1990) Embryological study of Herminium monorchis (Orchidaceae) and using confocal scanning laser microscopy. American Journal of Botany 77:123-127.

Gasser CS, Broadhvest J and Hauser BA (1998) Genetic analysis of ovule development. Annu Rev Plant Physiol Plant Mol Biol 49:1-24.

Grossniklaus U and Schneitz K (1998) The molecular and genetic basis of ovule and megagametophyte development. Cell and Developmental Biology, 9:227-238.

Johansson M and Wales AB (1993) Functional anatomy of the ovule in broad bean (Vicia faba L.). I. Histogenesis prior to and after pollination. Intl J Plant Sci 154:80-89.

Kapil RN and Bhatnagar AK (1981) Ultrastructure and biology of female gametophyte in flowering plants. Citology 70:291337.

Kennell JC and Horner HT (1985) Megasporogenesis and megagametogenesis in soybean, Glycine max. American Journal of Botany 72(10):1553-1564.

Maheshwari P (1950) An Introduction to the Embryology of Angiosperms. McGraw-Hill, New York, pp 453.

Pereira TNS, Louro R and Hoffmann M (1997) Estudo da esterilidade em flores sem curvatura (SC) de maracujá amarelo (Passiflora edulis f. flavicarpa Deg.). In: II Iberoamericano e III Congresso Ibérico de Ciências Hortícolas. Algarve, Vila Moura, Portugal, Resumos, pp 39.

Pereira TNS, Ilarslan H and Palmer RG (1996) Embryological study of a female partially sterile soybean mutant using confocal scanning laser microscopy. Brazilian Journal of Genetics 19(3):435-440.

Reiser L and Fischer RL (1993) The ovule and the embryo sac. Plant Cell 5:1291-1301.

Robinson-Beers K, Pruitt RE and Gasser CS (1992) Ovule development in wild-type Arabidopsis and two female-sterile mutants. The Plant Cell 4:1237-1249.

Ruggiero C (1973) Estudos sobre floração e polinização do maracujá amarelo (Passiflora edulis f. flavicarpa). Master Thesis. FCAV Jaboticabal, SP.

Ruggiero C, Lam-Sanchez A and Miguel S (1976) Estudos sobre a fertilidade de grãos de pólen de maracujá amarelo Passiflora edulis f. flavicarpa Deg. Congresso Brasileiro de Fruticultura 3:515-519.

Vanderplank J (1991) Passion flowers. ${ }^{\text {st }}$. Ed. Cassel Publishers Limited, London, pp 76. 